\title{
Effect of Concept Attainment Model on Achievement in Social Sciences
}

\author{
Dr. Ruchi Bhargava \\ Assistant Professor, Khalsa College of Education, Ranjit Avenue, Amritsar
}

\begin{abstract}
The present study investigates the effect of Concept Attainment model of teaching on achievement in Social Sciences. The sample consisted 74 students of class $9^{\text {th }}$ selected from two different schools of Amritsar (Punjab). Instructional material based on Concept Attainment model of teaching was prepared and utilized to teach the experimental group. After pre-testing and post-testing on all the students, gain scores were compute. Mean, S.D, and t-ratio were used to arrive at the conclusion that the performance of Concept Attainment model of teaching group was found significantly higher as compared to the control group.
\end{abstract}

Keywords: Teaching Models, Concept Attainment model, Achievement, Traditional Teaching Method

\section{Introduction}

The process of teaching learning aims at transmission of knowledge imparting skills and formulation of attitudes, values and behaviour. Teaching is a complex activity, which is a cluster of different roles and responsibilities. A teacher has to master multiple roles in order to become more professional. The professional competence can be expanded in two ways: first by increasing the range of teaching strategies that are needed to be employed; second by becoming increasingly skilful in the case of these strategies (Joyce \& Weil, 1972). The purpose of teaching is to maximize learning.

Bruner (1972) emphasized four major features of theory of instruction in effective teaching:

1. Predisposition towards learning

2. Structural body of knowledge

3. Sequences of material to be learnt

4. The nature and pairing of reward and punishment.

It means that a theory of instruction in teaching is concerned with how what one wishes to teach can best be learnt, with improving rather than describing teaching. It is true that teaching is a process by which teacher and students create a shared environment including sets of values and beliefs, which in turn colour their view of reality.

For the effective instructions, teaching models are the best way to transit effective learning. Traditionally, models of teaching are represented by a broad array of teaching systems, each system containing a distinctive philosophical foundation, or theory of learning basis, with related pedagogical methodologies. Most models can be loosely fitted into one of four or five distinct families of educational psychology -social; information-processing; personal; behavioural systems are the traditional ones, with constructivist added lately.

In teaching model of concept attainment, concept is a category or class of stimuli (objects, events, ideas, people and except them) in one or more common characteristics or features. Learning concept means placing objects or issues in a class, thus it can identify the class members. Each concept has definition, title or name, concepts and principles constitute the bulk of the course content. We summarize world with conceptualization in our mind. Concept has an important feature that knowing them will help the learner in better understanding of concept. It includes concept attribute, value of concept attribute, number of concept adjectives, adjectives of index, defining attributes, the original model, sample, classify concepts, objective and abstract concepts, concepts of combination and noncombination

This model is important to learn how to classify, how to think and how to receive the concept to students. In this model teacher is supporting and guidance of students' assumptions. Moreover, it is already select and organizes in concepts of positive and negative samples and leads learners to achieve this concept.

Stages of Teaching Model of Concept attainment

\begin{tabular}{|c|c|c|}
\hline Steps & Teacher actions & Inclusive activities \\
\hline First & $\begin{array}{l}\text { Offering examples and non- } \\
\text { examples In two columns } \\
\text { (yes) or (no) or }(+) \text { and }(-)\end{array}$ & $\begin{array}{c}\text {-Thinking and formulating } \\
\text { hypotheses about the concept } \\
\text { - Comparison of examples } \\
\text { and non-examples } \\
\text {-Naming concept in their } \\
\text { minds }\end{array}$ \\
\hline $\begin{array}{l}\text { Second } \\
\text { (a) }\end{array}$ & $\begin{array}{l}\text { Just provide examples, } \\
\text { without putting them in two } \\
\text { columns (yes) or (no). }\end{array}$ & $\begin{array}{l}\text { Examples and non-examples } \\
\text { of teachers placed in two } \\
\text { columns (yes) or (no) }\end{array}$ \\
\hline $\begin{array}{l}\text { Second } \\
\text { (b) }\end{array}$ & $\begin{array}{l}\text { Recorded examples and non- } \\
\text { examples of students } \\
\text {-Confirm or reject of } \\
\text { hypotheses } \\
\text { - providing the name of the } \\
\text { concept desired }\end{array}$ & $\begin{array}{l}\text { Learners provide examples } \\
\text { and are placed In the } \\
\text { appropriate column }\end{array}$ \\
\hline Third & $\begin{array}{l}\text {-providing definitions of the } \\
\text { concept } \\
\text {-analyzing and summarizing } \\
\text { Contents }\end{array}$ & $\begin{array}{l}\text {-Talk about hypotheses } \\
\text { - Description of their } \\
\text { thoughts about the concept } \\
\text { desired }\end{array}$ \\
\hline
\end{tabular}

This model enables students to advanced conceptualizing, specific concepts, inductive reasoning, dominance and knowledge of the visions, perspectives, tolerance of ambiguity and sensitivity to logical reasoning in communication. 


\section{International Journal of Science and Research (IJSR) \\ ISSN (Online): 2319-7064}

Index Copernicus Value (2013): 6.14 | Impact Factor (2015): 6.391

Fraizer (1999) introduced model of concept attainment, goals, teacher duty and students and the application of this model from preschool to high school, meanwhile the effectiveness of this model in various learning introduced constructive material of sweets and differences between meat foods, vegetable foods and restaurant foods by using concept attainment.

Verma (2001) reported that integrated teaching strategy improves the inductive reasoning ability of the students. Sreelekha and Nayar (2004) conducted a study to compare the achievement level between traditional method and concept attainment model with respect to knowledge objectives, understanding objectives and application objectives. The major finding was CAM was effective in improving the overall level of achievement in chemistry. Shamnad (2005) in his study found that the concept attainment model is more effective than control method in teaching Arabic grammar in standard IX.

Kalani (2008) in a study found that achievement of students who were taught by concept attainment model was better than those who taught by the control method. Yaghini (2008) in her study concluded that there is relationship between preschool children learning who trained numerical mathematics concepts by concept attainment and children in traditional group. Vyas (2014) in his study found that effect of concept attainment model of instruction was significantly higher on the over, normal and under achiever students. Ostad and Soleymanpou (2014) reported that teaching model of concept attainment and mastery affect levels of academic achievement and cognitive skills of students.

Researcher conducted on concept attainment model depicts that student's learn better when taught through this model. However, studies determining the effectiveness of concept attainment model on academic achievement of students in social sciences are very sketchy. Therefore this study was undertaken to find out the effectiveness of concept attainment model of teaching on achievement in social sciences.

\section{Objectives}

- To find out the effectiveness of concept attainment model of teaching on achievement in social sciences.

- To find out the effectiveness of traditional method of teaching on achievement in social sciences.

- To compare the effectiveness of concept attainment model of teaching with traditional method of teaching in social sciences.

\section{Hypotheses}

$\mathrm{H}_{1}$ : There exists no significant difference between students achievement in social sciences on the pre-test.

$\mathrm{H}_{2}$ : There exists no significant difference between students achievement in social sciences on the post-test taught through concept attainment model of teaching and traditional method.

$\mathrm{H}_{3}$ : There is no significant difference between the experimental group and control group in achievement in social sciences.

\section{Sample}

Purposive sampling technique was used. The study was conducted on a sample of 74 students of class IX.

\section{Tools}

- Intelligence test, developed by Dr. S.S. Jalota was used for selection of groups.

- Achievement test in social sciences prepared by investigator.

\section{Procedure}

In the present study experimental method was used to collect data. Pre-test-post-test experimental design was used in the study. Intelligence test, developed by Dr. S.S. Jalota was used for selection of groups. Students of both experimental and control groups were selected on the basis of their intelligence score. The students were divided into two group's i.e. experimental group and control group. The experimental group was taught through concept attainment model of teaching and the control group was taught through traditional method. The effectiveness of concept attainment model on achievement in social sciences was determined by administering the achievement test on both groups of students. Self-constructed achievement test was used for finding the achievement of students in social sciences.

\section{Result and Discussion}

Table 1: Data and result of the test of significance of the difference between the means of pre-test scores of pupils in the experimental and control groups

\begin{tabular}{|c|c|c|c|c|c|c|c|c|}
\hline \multirow{3}{*}{$\frac{\text { Variable }}{\text { pre-test }}$} & \multicolumn{3}{|c|}{ Experimental group } & \multicolumn{3}{|c|}{ Control group } & $t$-value & Level of significance \\
\hline & $\mathrm{N}$ & $\mathrm{M}$ & SD & $\mathrm{N}$ & $\mathrm{M}$ & SD & \multirow[t]{2}{*}{1.53} & \multirow[t]{2}{*}{ NS } \\
\hline & 36 & 28.40 & 1.724 & 38 & 27.75 & 2.446 & & \\
\hline
\end{tabular}

NS- Not Significant

Table 1 indicates that t-value (1.53) is not significant at 0.05 level of significance. So the null hypothesis that there exists no significant difference between students achievement in social sciences on the pre-test is accepted and it is concluded that there is no significant difference between the achievements of both groups.

Table 2: Data and result of the test of significance of the difference between the means of post-test scores of pupils in the experimental and control groups

\begin{tabular}{|c|c|c|c|c|c|c|c|c|}
\hline Variable & \multicolumn{3}{|c|}{ Experimental group } & \multicolumn{3}{|c|}{ Control group } & t-value & Level of significance \\
\hline post-test & $\mathrm{N}$ & $\mathrm{M}$ & $\mathrm{SD}$ & $\mathrm{N}$ & $\mathrm{M}$ & $\mathrm{SD}$ & 8.84 & 0.01 \\
\cline { 2 - 7 } & 36 & 41.55 & 1.67 & 38 & 29.12 & 8.73 & & \\
\hline
\end{tabular}




\section{International Journal of Science and Research (IJSR) \\ ISSN (Online): 2319-7064 \\ Index Copernicus Value (2013): 6.14 | Impact Factor (2015): 6.391}

Table 2 indicates that t-value (8.84) is not significant at 0.01 level of significance. So the null hypothesis that there exists no significant difference between student's achievement in social sciences on the post-test taught through concept attainment method and traditional method is rejected and it is concluded that there is significant difference between the achievements of both groups.

Table 3: Difference between the experimental and control groups

\begin{tabular}{|c|l|l|l|l|l|l|l|l|l|}
\hline Variable & \multicolumn{3}{|c|}{ Experimental group } & \multicolumn{3}{c|}{ Control group } & \multicolumn{1}{c|}{$\begin{array}{c}\text { Mean } \\
\text { Diff. }\end{array}$} & t-value & \multicolumn{1}{c|}{$\begin{array}{c}\text { Level of } \\
\text { significance }\end{array}$} \\
\hline Gain Score & $\mathrm{N}$ & $\mathrm{M}$ & $\mathrm{SD}$ & $\mathrm{N}$ & $\mathrm{M}$ & $\mathrm{SD}$ & 6.41 & 5.65 & 0.01 \\
\cline { 2 - 7 } & 36 & 40.17 & 3.20 & 38 & 34.52 & 4.56 & & & \\
\hline
\end{tabular}

Table 3 indicates that data of the experimental and control group in achievement in social sciences. The mean score of the experimental group is 40.17 and that of group is 34.52 . The SD of the experimental group is 3.20 and that of the control group is 4.56 . The mean difference between the two groups is 5.65 . The t-value is 6.41 which are significant at both the levels. It shows that null hypothesis that there is no significant difference between the experimental group and control group in their achievement in social sciences is rejected. It can be said that achievement of the experimental group in social sciences is higher than that of the control group.

\section{Conclusion}

In this study an attempt was made to explore the effectiveness of concept attainment model on achievement in social sciences. Concept attainment model was found to be effective in influencing the achievement level of class IX students in social sciences. It helps to clarify ideas and to introduce aspects of content. Achievement level of the students in social sciences taught through concept attainment model was found to be higher than the achievement level of students taught through traditional method. The students of experimental group were looking well motivated and ready to learn through the concept attainment model.

\section{References}

[1] Bruner, J.T. (1993). School for thought- A science of learning in the classroom. New York: Cambridge University Press.

[2] Fraizer, J. (1999). An educator's reference desk lesson plan: Concept attainment model. Boulangerie (Bakery): Randolph Macon Women's College.

[3] Joyce, B.R., \& Weil, M. (1972). Models of Teaching. United States of America: Prentice Hall.

[4] Kalani, A. (2008). A study of effectiveness of concept attainment model over control method for teaching science in relation to achievement and retention. International Research Journal, 2 (5), 20-22.

[5] Shamnad, N. (2005). Effectiveness of concept attainment model on achievement in arabic grammar of standard IX students. Retrieved May 2, 2016 from http://arabicuniversitycollege.yolasite.com/resources/Fa culty/NS/Dissertations

[6] Sreelekha, S. \& Nayar, A.K. (2004). The effectiveness of concept attainment model in learning chemistry at secondary level. New Delhi: NCERT publication.

[7] Ostad, G., \& Soleymanpour, J. (2014). The impact of concept attainment teaching model and mastery teaching method on female high school students' academic achievement and metacognitive skills. International Journal of Innovative Research in Science, Engineering and Technology, 3(2), 5-8.

[8] Verma, C.P. (2001). A comparative study of the effectiveness of mastery learning model and inductive thinking model on pupils' achievement in science and their creative thinking abilities. Unpublished Doctorate Thesis, Rohtak: M.D.University.

[9] Vyas, B.K. (2014). Effect of concept attainment model of instruction on achievement in mathematics of under achiever and over achiever students of secondary schools. Unpublished Doctorate Thesis, Rajkot: Saurashtra University

[10] Yaghini, M. (2008). Evaluating the effects of concept attainment teaching model and traditional on the learning concepts of numerical mathematics during preschool from the perspective of educators in Shiraz. Unpublished Master's thesis, Iran: Islamic Azad University, Arsanjan. 